ISSN 1678-3921

Journal homepage: www.embrapa.br/pab

For manuscript submission and journal contents, access: www.scielo.br/pab
Humberto Sampaio de Araújo(1凶) Roberto Botelho Ferraz Branco(2) Carolina Cinto de Moraes $^{(3)}$, Alex Humberto Calori ${ }^{(3)}$, Amarílis Beraldo Rós ${ }^{(4)}$ and Luis Felipe Villani Purquerio(3)

(1) Agência Paulista de Tecnologia dos Agronegócios, Polo Regional Extremo Oeste, Estrada Vicinal Nemezião de Souza Pereira, Km 06, Caixa Postal 67 CEP 16900-970 Andradina, SP, Brazil. E-mail: humbertosaraujo@apta.sp.gov.br

(2) Agência Paulista de Tecnologia dos Agronegócios, Polo Regional Centro Leste, Avenida dos Bandeirantes, № 2.419 CEP 14030-670 Ribeirão Preto, SP, Brazil. E-mail: branco@apta.sp.gov.br

(3) Instituto Agronômico, Avenida Barão de Itapura, $n$ o 1.481, CEP 13020-902 Campinas, SP, Brazil.

E-mail: carolcmoraes@hotmail.com, ahcalori@gmail.com, felipe@iac.gov.sp.br

(4) Agência Paulista de Tecnologia dos Agronegócios, Polo Regional Alta Sorocabana, Rodovia Raposo Tavares, Km 561, Caixa Postal 298, CEP 19015 970 Presidente Prudente, SP, Brazil. E-mail: amarilis@apta.sp.gov.br

${ }^{\otimes}$ Corresponding author

Received

August 14, 2017

Accepted

March 19, 2018

How to cite

ARAÚJO, H.S. de; BRANCO, R.B.F. MORAES, C.C. de; CALORI, A.H.; RÓS, A.B.; PURQUERIO, L.F.V. Watermelon cultivation in regeneration areas of a sugarcane field under different soil management. Pesquisa Agropecuária Brasileira, v.54, e00039, 2019. DOI: https://doi.org/10.1590/S1678-3921. pab2019.v54.00039.

\section{Watermelon cultivation in regeneration areas of a sugarcane field under different soil managements}

\begin{abstract}
The objective of this work was to evaluate watermelon (Citrullus lanatus) cultivation in regeneration areas of a sugarcane field, under different soil management systems and $\mathrm{N}$ fertilization regimes. Two experiments were carried out in the 2014/2015 and 2015/2016 harvest seasons, in areas of sugarcane plantation in Andradina, in the state of São Paulo, Brazil. Cultivations were performed in a randomized complete block design, with plots and subplots, and four replicates. The plots represented the tillage systems (conventional, minimum tillage, and no-tillage), and the subplots, the different $\mathrm{N}$ fertilization rates $\left(0,100,200\right.$, and $\left.300 \mathrm{~kg} \mathrm{ha}^{-1}\right)$ applied as topdressing. In 2014/2015, the minimum tillage system resulted in the highest commercial yield of $70.2 \mathrm{Mg} \mathrm{ha}^{-1}$. In 2015/2016, there were no differences for yield among tillage systems; however, yield differed among $\mathrm{N}$ treatments. The highest commercial yields of 64.1 and $31.1 \mathrm{Mg} \mathrm{ha}^{-1}$ were achieved with the $\mathrm{N}$ doses of 253 and $209 \mathrm{~kg} \mathrm{ha}^{-1}$ as topdressing, respectively, in 2014/2015 and 2015/2016. Watermelon can be cultivated in regeneration areas of sugarcane field, and the demand of $\mathrm{N}$ by the plant does not depend on the soil tillage system.
\end{abstract}

Index terms: Citrullus lanatus, conservational system, crop rotation, nitrogen fertilization.

\section{Cultivo de melancia em áreas de renovação de canavial sob diferentes manejos do solo}

Resumo - O objetivo deste trabalho foi avaliar o cultivo de melancia (Citrullus lanatus) em áreas de renovação de canavial, em diferentes sistemas de preparo do solo e adubação nitrogenada. Foram realizados dois experimentos nas safras de 2014/2015 e 2015/2016, em áreas de plantio de cana-de-açúcar, em Andradina, no Estado de São Paulo, Brasil. Os cultivos foram feitos em delineamento experimental de blocos ao acaso, com parcelas, subparcelas e quatro repetições. As parcelas representaram os sistemas de preparo do solo (plantio convencional, cultivo mínimo e plantio direto), e as subparcelas, as diferentes doses de $\mathrm{N}$ aplicadas em cobertura (0, 100, 200 e $\left.300 \mathrm{~kg} \mathrm{ha}^{-1}\right)$. Em 2014/2015, o cultivo mínimo apresentou a maior produtividade comercial de $70,2 \mathrm{Mg} \mathrm{ha}^{-1}$. Em 2015/2016, não houve diferenças quanto à produção entre os tratamentos de preparo de solo; porém, a produção diferiu entre os tratamentos com $\mathrm{N}$. As maiores produtividades comerciais de 64,1 e $31,1 \mathrm{Mg} \mathrm{ha}^{-1}$ foram obtidas com as doses de 253 e $209 \mathrm{~kg} \mathrm{ha}^{-1}$ de $\mathrm{N}$ em cobertura, respectivamente, em 2014/2015 e 2015/2016. A melancia pode ser cultivada em áreas de renovação de canavial, e a demanda de $\mathrm{N}$ pela planta não depende do sistema de preparo de solo.

Termos para indexação: Citrullus lanatus, cultivo conservacionista, rotação de culturas, adubação nitrogenada. 


\section{Introduction}

Brazil is the world's largest producer of sugarcane, with the annual harvest of 684 million tons in the 2016/2017 harvest (Acompanhamento..., 2016). After planting, crop productivity decreases year after year, until replanting is done after an average of 5 years. This agricultural practice is known as crop rotation (Santiago \& Rossetto, 2008). This practice is usually performed in periods of higher rainfall, and it involves processes such as grazing and subsoiling, which causes soil losses owing to erosion (Bolonhezi et al., 2007). The adoption of mechanized sugarcane harvesting stimulated the gradual elimination of fires that resulted in the deposition of a large amount of straw and dry matter on the soil surface. Most of the replanting areas remain unoccupied from the end of the harvest to the beginning of replanting, allowing of the implementation of planting practices for the conservation management (Bolonhezi et al., 2007) of sugarcane straw by crop rotation. Previous studies evaluated sugarcane crop rotation with peanuts (Bolonhezi et al., 2007; Barbosa et al., 2014), soybean (Finoto et al., 2015), and green manure (Ambrosano et al. 2011). However, to the best of our knowledge, no studies have evaluated crop rotation with vegetables until present. Therefore, watermelon (Citrullus lanatus) cultivation, which has a high socioeconomic importance in tropical regions, provides an option of encouraging the cultivation of food crops in sugarcane regeneration areas. Watermelon is one of the main cucurbits cultivated in Brazil; it is planted in a 94,375 ha area, and its yield is $2,171,448 \mathrm{Mg}$ per year (FAO, 2014). Watermelon is grown in the state of São Paulo, primarily in sandy soils (Branco et al., 2014), in degraded pasture lands. Watermelon cultivation requires $\mathrm{N}$ as one of the most important nutrients whose deficiency limits this crop productivity (Grangeiro \& Cecílio Filho, 2004; Leão et al., 2008). The recommended fertilizer application for watermelon growth in São Paulo state is from 80 to $130 \mathrm{~kg} \mathrm{ha}^{-1} \mathrm{~N}$ (Trani et al., 1997) during the crop cycle.

Few studies have evaluated the conservation management of watermelon cultivation. Rocha et al. (2011) compared the use of conventional tillage, minimum tillage, and no-tillage systems with a scarifier, and observed that the highest yield occurred in conventional tillage (126.5 $\left.\mathrm{Mg} \mathrm{ha}^{-1}\right)$, whereas that in the no-tillage treatment was lower $\left(74.1 \mathrm{Mg} \mathrm{ha}^{-1}\right)$. In no-tillage systems, the presence of straw on the soil surface changes the physical, chemical, and biological soil properties, leading to an higher soil fertility and yield than those in the conventional tillage system (Bernoux et al., 2006; Tivelli et al., 2010). The use of straw in no-tillage systems facilitates the colonization by microorganisms, in contrast to conservation tillage systems (Simpósio..., 2007). Therefore, different soil tillage systems may differently affect the flow of water and nutrients, including $\mathrm{N}$.

Predicting $\mathrm{N}$ dynamics in soils under no-tillage systems is difficult because this dynamics depends on the rate of straw decomposition and on the amount of available $\mathrm{N}$ for the rotation crop. Therefore, the $\mathrm{N}$ concentration supply to the crop depends on the $\mathrm{N}$ level available in the soil. The amount of $\mathrm{N}$ released from the straw during the next cycle of sugarcane cultivation may vary from 3 to $30 \%$ (Vitti et al., 2008, 2010). However, studies show that the $\mathrm{N}$ incorporation by the mineralization of straw increases significantly with longer cultivation periods, and decreases with shorter cultivation periods (Vitti et al., 2011; Fortes et al., 2013); this may be the case with watermelon cultivation. Because of changes in the physical, chemical, and biological soil properties under different tillage systems, complementary nutritional studies are necessary to ensure adequate rates and periods of $\mathrm{N}$ application to avoid excess or lack of nutrients to the crops.

The objective of this work was to evaluate the watermelon cultivation in regeneration areas of a sugarcane field under different soil management systems and $\mathrm{N}$ fertilization regimes.

\section{Materials and Methods}

Two experiments were carried out during the 2014/2015 and 2015/2016 harvest seasons in sugarcane fields, in the municipality of Andradina, in the state of São Paulo, Brazil. The geographic coordinates of this municipality are $20^{\circ} 45^{\prime}$ and $20^{\circ} 46^{\prime} \mathrm{S}$ and $51^{\circ} 22^{\prime}$ and $51^{\circ} 22^{\prime} \mathrm{W}$, at $379 \mathrm{~m}$ altitude.

Both sugarcane crops, each in a 30 ha area, were replanted after the seventh consecutive harvest, when the yield of sugarcane 'RB 83 5486' was less than $60 \mathrm{Mg} \mathrm{ha}^{-1}$. In the year before the installation of both experiments, weeds in the ratoon cane were managed in September with herbicides, using $1 \mathrm{~L} \mathrm{ha}^{-1}$ clomazone, and $1.5 \mathrm{~kg} \mathrm{ha}^{-1}$ diuron with hexazinone.

Pesq. agropec. bras., Brasília, v.54, e00039, 2019

DOI: 10.1590/S1678-3921.pab2019.v54.00039 
The soil was classified as Latossolo Vermelho (Santos et al., 2006). The soil chemical analyses at $0-0.20 \mathrm{~m}$ soil depth, before starting the experiments in the 2014/2015 and 2015/2016 seasons, were respectively the following ones: $\mathrm{pH}_{(\mathrm{CaCl} 2)}, 5.1$ and 5.9; $\mathrm{P}_{\text {resine, }} 26$ and $10 \mathrm{mg} \mathrm{dm}^{-3}$; organic matter, 10 and $12 \mathrm{~g} \mathrm{dm}^{-3}$; base saturation (V), 64 and $63 \%$; $\mathrm{H}+\mathrm{Al}$, 16 and $16 \mathrm{mmol}_{\mathrm{c}} \mathrm{dm}^{-3} ; \mathrm{K}, 1.0$ and $1.1 \mathrm{mmol}_{\mathrm{c}} \mathrm{dm}^{-3}$; $\mathrm{Ca}, 24$ and $17 \mathrm{mmol}_{\mathrm{c}} \mathrm{dm}^{-3} ; \mathrm{Mg}, 3$ and $9 \mathrm{mmol}_{\mathrm{c}} \mathrm{dm}^{-3}$; sum of bases (SB), 28 and $27 \mathrm{mmol}_{\mathrm{c}} \mathrm{dm}^{-3}$; cation exchange capacity (CEC), 44 and $43 \mathrm{mmol}_{\mathrm{c}} \mathrm{dm}^{-3}$. No liming was performed in the experimental areas, and chemical fertilization was applied in the crop rows using $30 \mathrm{~kg} \mathrm{ha}^{-1} \mathrm{~N}$ (urea), $240 \mathrm{~kg} \mathrm{ha}^{-1} \mathrm{P}_{2} \mathrm{O}_{5}$ (triple superphosphate), and $150 \mathrm{~kg} \mathrm{ha}^{-1} \mathrm{~K}_{2} \mathrm{O}$ (potassium chloride). Cover fertilization was performed using $100 \mathrm{~kg} \mathrm{~K}_{2} \mathrm{O} \mathrm{ha}^{-1}$ divided into three applications at 15 , 30 , and 50 days after emergence.

After harvest, sugarcane crop regrowth was dried using glyphosate ( $3 \mathrm{~kg} \mathrm{ha}^{-1}$ i.a.), and the soil was tilled. For watermelon planting, 'Olímpia' hybrid was manually sown on October 6, 2014 and October 6, 2015. Cultivation practices were adopted considering the needs of the crop, and irrigation was performed by sprinkling, using the central pivot system.

Four replicates of each treatment were arranged in a randomized complete block design. The main plots, with $192 \mathrm{~m}^{2}$, included three tillage systems: conventional, minimum, and no-tillage. Conventional tillage involved the incorporation of sugarcane straw into the soil, after harvest, using a disk plow, and later, a disk harrow. Minimum tillage was performed by subsoiling at $0.60 \mathrm{~m}$ soil depth in the crop rows, and no-tillage, by opening crop rows to $0.03 \mathrm{~m}$ soil depth using a seeder for direct seeding of grains. In the minimum tillage and no-tillage systems, most of the area was covered with sugarcane straw. The subplots corresponded to different $\mathrm{N}$ concentrations $(0,100$, 200 , and $300 \mathrm{~kg} \mathrm{ha}^{-1}$ ) in the soil cover, in the form of ammonium nitrate $(33.5 \% \mathrm{~N})$, divided into three treatments at 15,30 , and 50 days after plant emergence. Spacing was $3.0 \mathrm{~m}$ between rows and $1.0 \mathrm{~m}$ between plants within each row. Each subplot was composed of two rows of eight plants each, with $8.0 \mathrm{~m}$ length by $6.0 \mathrm{~m}$ width, totaling $48.0 \mathrm{~m}^{2}$. A border plant was left at each end of the subplots, and $10.0 \mathrm{~m}$ space was left between the plots to prevent the main rows from overlapping.
One week before watermelon planting, 10 sugarcane straw samples were collected from the experimental area where straw had not been incorporated in the soil. This procedure was repeated biweekly until 75 days after sowing (DAS), next to the experimental area. The straw samples were collected, using a $0.25 \mathrm{~m}^{2}$ template $(0.5 \times 0.5 \mathrm{~m})$, and dried in a forced-circulation air oven at $65^{\circ} \mathrm{C}$, for determining the mass of straw dry matter. These measurements were subjected to regression analysis.

The following production characteristics were evaluated: total and commercial number and total fruit per plant, diameter and length of commercial fruit (m), total and commercial production of fruit (grams per plant), and total and commercial yield $\left(\mathrm{Mg} \mathrm{ha}^{-1}\right)$ of fruit. The data were subjected to the analysis of variance and F-test. The effect of $\mathrm{N}$ concentrations was evaluated using the regression analysis, and the criterion for choosing the model was the magnitude of the coefficients of regression. Tukey's test was used for analyzing the data on the soil preparation, at the $5 \%$ probability. Data obtained from the two harvests were analyzed in combination, when the relationship between the residual mean squares of the individual analyses of variance of each crop did not exceed the 7:1 ratio (Banzatto \& Kronka, 2006). Software Sisvar version 5.3 (Ferreira, 2011) was used in the statistical analyses.

\section{Results and Discussion}

In the 2014/2015 and 2015/2016 harvest seasons, the conditions of the tests (genetic material, cultivation practices, soil and relief classifications) were similar, but the climatic conditions differed. In the 2014/2015 season, rainfall was $327.6 \mathrm{~mm}$, which was similar to the historical average of the region, whereas in the $2015 / 2016$ season, rainfall was $715 \mathrm{~mm}$, which was $78 \%$ higher than the historical average of the region in the period (CIIAGRO, 2016). The increased precipitation limited the control of fungal diseases and caused crop yield decrease (Figure 1). The mean maximum and minimum temperatures varied from 20.9 to $33.3^{\circ} \mathrm{C}$ in the first year, and from 20.8 to $34.5^{\circ} \mathrm{C}$ in the second year; these values are similar to the historical average of the region in the period $\left(18.7-32.7^{\circ} \mathrm{C}\right)$ (CIIAGRO, 2016). 
One week before watermelon sowing, the mean yield of straw dry matter in the experimental areas, in 2014/2015 and 2015/2016 seasons, was 14.5 and $15.8 \mathrm{Mg} \mathrm{ha}^{-1}$, respectively. These values are close to those (8-20 $\left.\mathrm{Mg} \mathrm{ha}^{-1}\right)$ found in the literature (Vitti et al., 2008; Trivellin et al., 2013).

The dry matter yield of sugarcane straw decreased over time in the biweekly harvests and fitted to the linear functions (Figure 2), indicating a decomposition rate of up to 9.4 and $7.5 \mathrm{Mg} \mathrm{ha}^{-1}$ straw dry mass, at 75 days after sowing, in the 2014/2015 and 2015/2016 harvests, respectively.
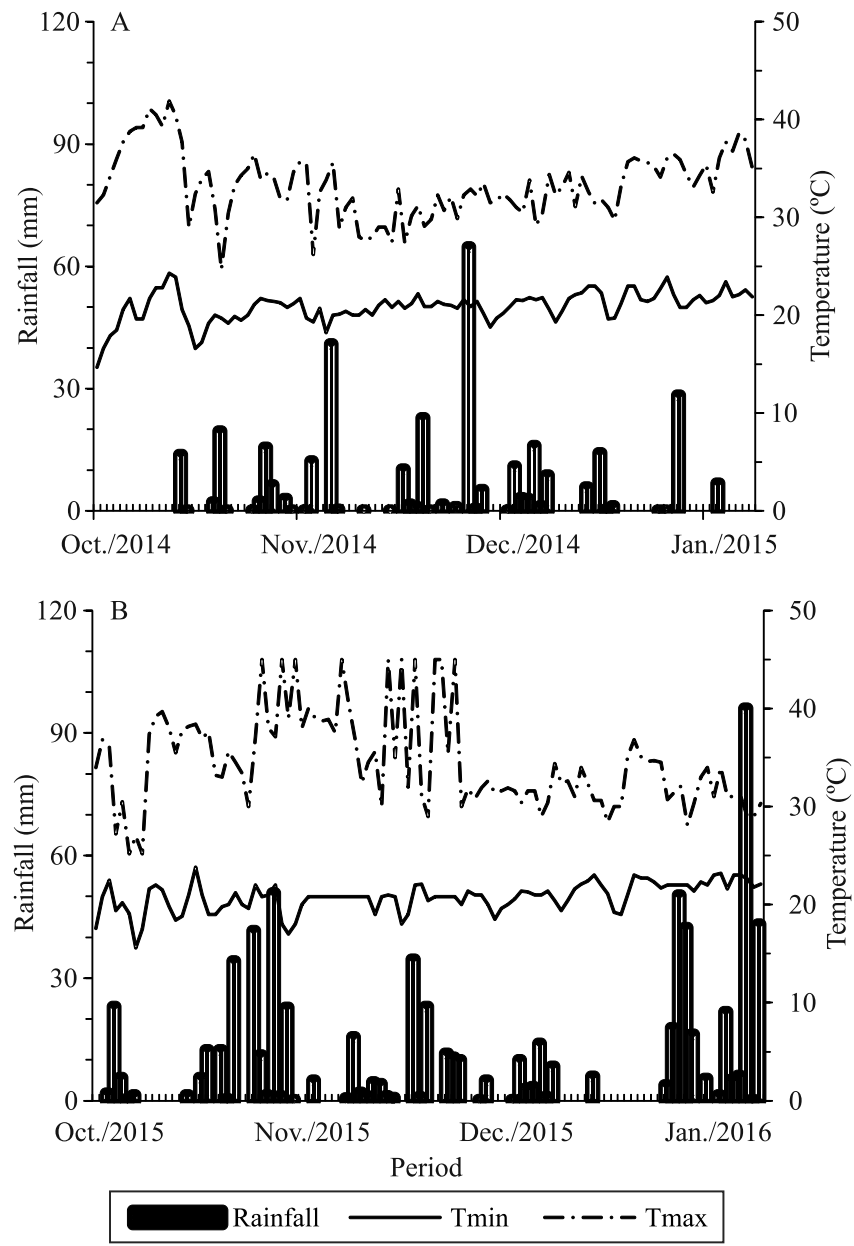

Figure 1. Rainfall, and maximum and minimum air temperatures recorded in two harvest seasons: A, 2014/2015; and B, 2015/2016, in the municipality of Andradina, in the state of São Paulo, Brazil.
There was no significant interaction between soil tillage and $\mathrm{N}$ concentrations applied to the soil cover $(p<0.05)$ in the two evaluated seasons. Therefore, the demand of $\mathrm{N}$ in watermelon production was the same, regardless of the soil tillage system adopted, with or without the incorporation of sugarcane straw. Farinelli et al. (2006) and Farinelli \& Lemos (2012) evaluated N fertilization in the soil cover in bean and maize crops, using conventional tillage and no-tillage treatments, respectively, and showed that beans required higher $\mathrm{N}$ concentrations in the no-tillage system because of the decreased straw decomposition. In contrast, the agronomic and nutritional characteristics of maize did not differ between tillage systems and $\mathrm{N}$ concentrations used, although the conventional tillage had caused higher losses of $\mathrm{N}$, and $\mathrm{N}$ application to the soil cover had promoted an increase in the incorporation of this nutrient by maize.

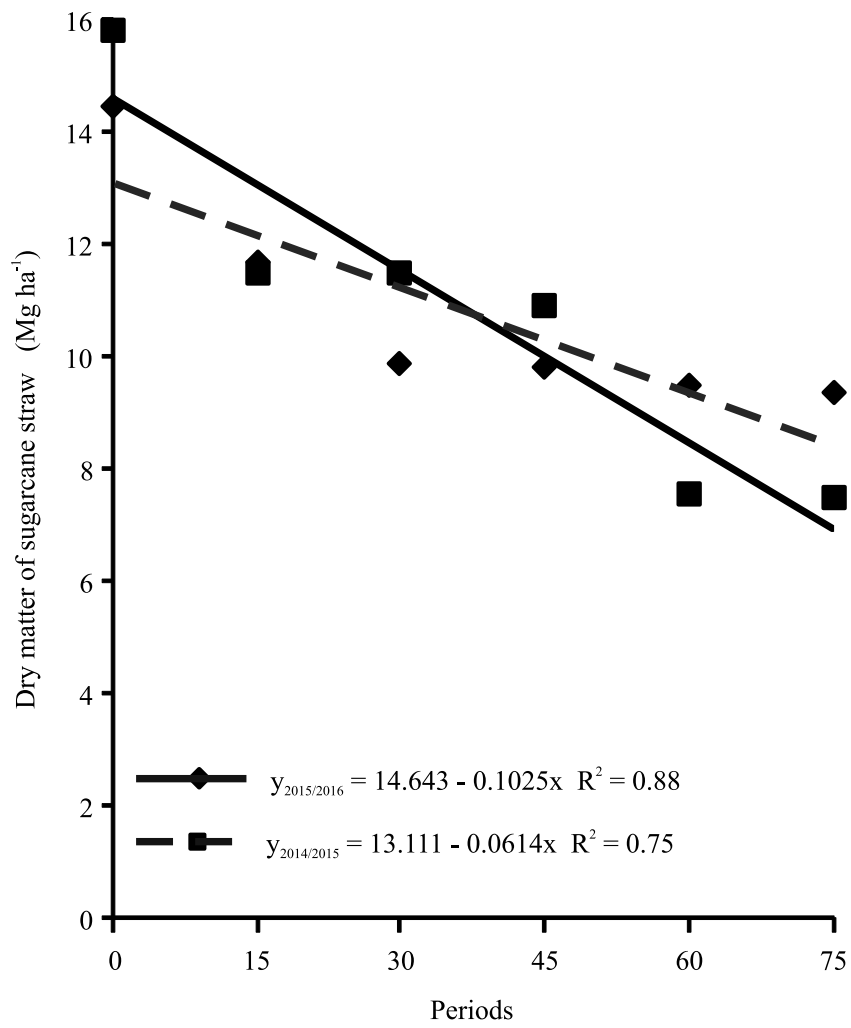

Figure 2. Effect of the collection time on the dry matter amount of sugarcane straw in the 2014/2015 and 2015/2016 harvest seasons, in the municipality of Andradina, in the state of São Paulo, Brazil. 
There was a significant effect of the treatments when they were analyzed independently. In the 2014/2015 season, tillage strongly affected the production characteristics of watermelon, except for the total and the commercial number of fruit, with 2.3 and 1.5 fruit per plant, respectively. In minimum tillage, the mean fruit diameter and length were 0.82 and $0.48 \mathrm{~m}$, respectively, which differed statistically from the means found for conventional tillage $(0.76$ and $0.46 \mathrm{~m})$ and no-tillage $(0.79$ and $0.47 \mathrm{~m})$ (Table 1$)$. Moreover, the total and commercial production and total and commercial yield varied among the treatments, and the highest means were observed in the minimum tillage system, corresponding to 23.0 and $21.0 \mathrm{~g}$ per plant, and 76.8 and $70.2 \mathrm{Mg} \mathrm{ha}^{-1}$, respectively. Commercial productivity in the minimum tillage system was 45 and $36 \%$ higher than that in the conventional tillage and no-tillage, respectively (Table 1). In the 2015/2016 season, the tillage system did not affect the evaluated production characteristics. The 2015/2016 season showed the following results: the mean total and commercial number of fruit per plant was 1.6 and 0.76 fruit, respectively; fruit diameter and length were 0.73 and $0.42 \mathrm{~m}$, respectively; total and commercial production were 9.4 and $6.7 \mathrm{~kg}$ per plant, respectively; and total and commercial yield were 31.5 and 22.3 Mg ha ${ }^{-1}$, respectively. Therefore, in the 2014/2015 season, the minimum tillage system showed the best results, with a mean commercial yield of $70.2 \mathrm{Mg} \mathrm{ha}^{-1}$. By contrast, in the $2015 / 2016$ season, there were no significant differences between the evaluated tillage systems, and the mean commercial yield was $22.3 \mathrm{Mg} \mathrm{ha}^{-1}$.

Other studies reported different results for watermelon cultivation under different tillage systems. Rocha et al. (2011) compared watermelon crops cultivated on oat straw using conventional, minimum, and no-tillage systems, and performed scarification with one to four disks. They concluded that the conventional tillage system was the best treatment, with the mean crop yield of $126.5 \mathrm{Mg} \mathrm{ha}^{-1}$. In this case, the higher soil mobilization increased the root surface area, resulting in a more homogeneous, horizontal, and deeper root system.

Silva et al. (2013) evaluated weed management of watermelon under no-tillage and conventional tillage systems. They concluded that the no-tillage system provided higher yield than the conventional tillage. Branco et al. (2014) compared watermelon cultivated on clover and oat straw under minimum tillage and notillage conditions, and observed that root development was restricted in the no-tillage system. However, commercial yield was similar between the treatments (27.4 $\mathrm{Mg} \mathrm{ha}^{-1}$ ), except for no-tillage using oat straw

Table 1. Total number of fruit per plant (TNF), number of commercial fruit per plant (NCF), fruit diameter, fruit length, total production (TP), and commercial production (CP), total yield, and commercial yield (CY) of watermelon 'Olímpia' (Citrullus lanatus), according to the tillage system used in the 2014/2015 and 2015/2016 harvest seasons ${ }^{(1)}$.

\begin{tabular}{|c|c|c|c|c|c|c|c|c|}
\hline \multirow[t]{2}{*}{ Soil preparation } & TNF & NCF & Fruit diameter & Fruit lenght & TP & $\mathrm{CP}$ & Total yield & $\mathrm{CY}$ \\
\hline & \multicolumn{2}{|c|}{ (number per plant) } & \multicolumn{2}{|c|}{-----------(m)----------- } & \multicolumn{2}{|c|}{-----(kg per plant)----- } & \multicolumn{2}{|c|}{--------(Mg ha-1)--------- } \\
\hline & \multicolumn{8}{|c|}{$2014 / 2015$ harvest season } \\
\hline Conventional tillage & $2.3 \mathrm{a}$ & $1.4 \mathrm{a}$ & $0.76 \mathrm{c}$ & $0.46 \mathrm{~b}$ & $17.6 \mathrm{~b}$ & $14.4 \mathrm{~b}$ & $58.8 \mathrm{~b}$ & $48.2 \mathrm{~b}$ \\
\hline Minimum tillage & $2.4 \mathrm{a}$ & $1.9 \mathrm{a}$ & $0.82 \mathrm{a}$ & $0.48 \mathrm{a}$ & $23.0 \mathrm{a}$ & $21.0 \mathrm{a}$ & $76.8 \mathrm{a}$ & $70.2 \mathrm{a}$ \\
\hline No-tillage & $2.3 \mathrm{a}$ & $1.3 \mathrm{a}$ & $0.79 \mathrm{~b}$ & $0.47 \mathrm{~b}$ & $19.1 \mathrm{ab}$ & $15.4 \mathrm{~b}$ & $63.7 \mathrm{~b}$ & $51.5 \mathrm{~b}$ \\
\hline DMS & - & - & 0.89 & 1.10 & 5.13 & 4.39 & 17.09 & 14.63 \\
\hline $\mathrm{F}$ & $0.47^{\text {ns }}$ & $5.61^{\mathrm{ns}}$ & $180.03 * *$ & $14.31^{* *}$ & $5.52 *$ & $12.48 * *$ & $5.52 *$ & $12.41 * *$ \\
\hline CV (1) \% & 23.96 & 34.22 & 1.05 & 2.15 & 23.72 & 23.84 & 23.72 & 23.84 \\
\hline \multirow[t]{2}{*}{$\mathrm{CV}(2) \%$} & 22.78 & 34.80 & 2.81 & 4.79 & 24.81 & 26.80 & 24.80 & 26.80 \\
\hline & \multicolumn{8}{|c|}{ 2015/2016 harvest season } \\
\hline Conventional tillage & $1.7 \mathrm{a}$ & $0.86 \mathrm{a}$ & $0.74 \mathrm{a}$ & $0.42 \mathrm{a}$ & $10.3 \mathrm{a}$ & $7.3 \mathrm{a}$ & $34.4 \mathrm{a}$ & $24.3 \mathrm{a}$ \\
\hline Minimum tillage & $1.5 \mathrm{a}$ & $0.79 \mathrm{a}$ & $0.74 \mathrm{a}$ & $0.43 \mathrm{a}$ & $9.4 \mathrm{a}$ & $7.0 \mathrm{a}$ & $31.3 \mathrm{a}$ & $23.4 \mathrm{a}$ \\
\hline No-tillage & $1.4 \mathrm{a}$ & $0.61 \mathrm{a}$ & $0.70 \mathrm{a}$ & $0.41 \mathrm{a}$ & $8.6 \mathrm{a}$ & $5.7 \mathrm{a}$ & $28.6 \mathrm{a}$ & $19.1 \mathrm{a}$ \\
\hline DMS & - & - & - & - & - & - & - & - \\
\hline $\mathrm{F}$ & $1.90^{\mathrm{ns}}$ & $3.12^{\text {ns }}$ & $1.10^{\mathrm{ns}}$ & $0.96^{\mathrm{ns}}$ & $2.30^{\mathrm{ns}}$ & $2.02^{\mathrm{ns}}$ & $2.32^{\mathrm{ns}}$ & $2.01^{\mathrm{ns}}$ \\
\hline CV (1) \% & 28.40 & 37.48 & 12.51 & 11.05 & 24.52 & 35.01 & 24.30 & 35.01 \\
\hline CV (2) \% & 26.90 & 37.37 & 14.51 & 15.17 & 25.56 & 33.07 & 25.63 & 33.10 \\
\hline
\end{tabular}

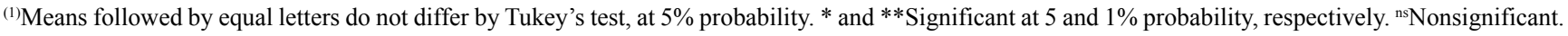


(17.9 $\left.\mathrm{Mg} \mathrm{ha}^{-1}\right)$. The combined analysis of the crops indicated that the production variables were affected by the planting season, except for the fruit diameter and length, which did not meet the conditions for this type of analysis. The variables evaluated in 2014/2015 were approximately two-fold higher than in 2015/2016 (Table 2). This difference can be attributed to adverse climatic conditions, particularly the rainfall in the 2015/2016 season.

In the 2014/2015 season, the highest fruit diameter and length, commercial production and yield were affected by the different $\mathrm{N}$ concentrations, which fitted with the quadratic regression model (Figure 3). In the 2015/2016 season, all the production variables were affected by different $\mathrm{N}$ levels, except for the total number of fruit. The mean values of these variables also fitted with the quadratic regression model.

In the 2014/2015 season, the highest fruit diameter and length, and the estimated commercial production and yield were $0.81 \mathrm{~m}, 0.48 \mathrm{~m}, 18.9 \mathrm{~kg}$ per plant, and $64.1 \mathrm{Mg} \mathrm{ha}^{-1}$, respectively, and these values were obtained using 195, 178, 241, and $253 \mathrm{~kg} \mathrm{ha}^{-1}$ $\mathrm{N}$ applications to the soil cover, respectively. In the 2015/2016 season, the highest total production and yield were $11.4 \mathrm{~kg}$ per plant and $37.5 \mathrm{Mg} \mathrm{ha}^{-1}$, respectively, using 233 and $185 \mathrm{~kg} \mathrm{ha}^{-1} \mathrm{~N}$ applications to the soil cover, respectively. In the $2015 / 2016$ season, the highest estimated number of commercial fruit, fruit diameter and length, and commercial production and yield were 1.0 fruit per plant, $0.78 \mathrm{~m}, 0.45 \mathrm{~m}$, and $8.9 \mathrm{~kg}$ per plant, and $31.1 \mathrm{Mg} \mathrm{ha}^{-1}$, respectively, using $195,219,227,174$, and $209 \mathrm{~kg} \mathrm{ha}^{-1} \mathrm{~N}$ application to the soil cover, respectively. In the state of São Paulo, the official recommendation for watermelon cultivation is the total application from 80 to $130 \mathrm{~kg} \mathrm{ha}^{-1} \mathrm{~N}$ (Trani et al., 1997). Barros et al. (2012) studied the effect of different $\mathrm{N}$ concentrations in the planting of watermelon 'Crimson Sweet'. They found that the highest yield (40.4 $\mathrm{Mg} \mathrm{ha}^{-1}$ ) was achieved using $144.4 \mathrm{~kg} \mathrm{ha}^{-1} \mathrm{~N}$, and this value is close to the official recommendation. In contrast, Soares et al. (2002) analyzed different doses of $\mathrm{N}$ for the growth of watermelon 'Crimson Sweet', and found that the highest yield $\left(64.9 \mathrm{Mg} \mathrm{ha}^{-1}\right)$ was obtained using $229.8 \mathrm{~kg} \mathrm{ha}^{-1} \mathrm{~N}$, which was close the value found in the present study.

Therefore, in the present work, the mean total $\mathrm{N}$ level (fertilization of crop and cover crop) that resulted in the highest yield was $93 \%$ higher than the highest recommended concentration, and some of the applied $\mathrm{N}$ was probably leached, volatilized, and immobilized by microorganisms. The amount of $\mathrm{N}$ leachate is particularly dependent on the amount of the applied $\mathrm{N}$, type of soil, and volume of precipitation (Nielsen et al., 1982). The residual sugarcane straw promotes changes in the production environment and increases the $\mathrm{C}: \mathrm{N}$ ratio. Fortes et al. (2012) observed that the C:N ratio of sugarcane straw initially varied from $70: 1$ to $108: 1$ but decreased along the harvests. The release of $\mathrm{N}$ by straw is slow, and its use by the subsequent crop is also low, according to Vitti et al. (2008), primarily because of the high initial C:N ratio of sugarcane straw, which favors the immobilization of $\mathrm{N}$ by soil microorganisms (Jingguo \& Bakken, 1997). Therefore, as compared with the official recommendations, the high-N concentrations applied for higher productivity in the present work may be related to the competition for this nutrient between plants and microorganisms.

Table 2. Comparison of total number of fruit per plant (TNF), number of commercial fruit per plant (NCF), fruit diameter (FD), fruit length (FL), total production (TP), and commercial production (CP), total yield (TY), and commercial yield (CY) of watermelon 'Olímpia' (Citrullus lanatus), in the 2014/2015 and 2015/2016 harvest seasons ${ }^{(1)}$.

\begin{tabular}{|c|c|c|c|c|c|c|c|c|}
\hline \multirow{2}{*}{$\begin{array}{l}\text { Harvest sea- } \\
\text { sons }\end{array}$} & $\mathrm{TNF}$ & $\mathrm{NCF}$ & FD & FL & $\mathrm{TP}$ & $\mathrm{CP}$ & TY & $\mathrm{CY}$ \\
\hline & \multicolumn{2}{|c|}{---(number per plant)--- } & \multicolumn{2}{|c|}{--1-- } & \multicolumn{2}{|c|}{-----(kg per plant)------ } & \multicolumn{2}{|c|}{------(Mg ha-1)------ } \\
\hline $2014 / 2015$ & $2.3 \mathrm{a}$ & $1.5 \mathrm{a}$ & - & - & $20.0 \mathrm{a}$ & $17.0 \mathrm{a}$ & $66.5 \mathrm{a}$ & $56.6 \mathrm{a}$ \\
\hline $2015 / 2016$ & $1.6 \mathrm{~b}$ & $0.7 \mathrm{~b}$ & - & - & $9.4 \mathrm{~b}$ & $6.7 \mathrm{~b}$ & $31.5 b$ & $22.3 b$ \\
\hline DMS & 0.24 & 0.16 & - & - & 1.80 & 1.59 & 5.91 & 5.30 \\
\hline $\mathrm{F}$ & $38.59 * *$ & $106.07 * *$ & - & - & $159.63 * *$ & $190.64 * *$ & $159.44 * *$ & $189.89 * *$ \\
\hline $\mathrm{CV}(1) \%$ & 28.97 & 32.40 & - & - & 27.72 & 30.38 & 27.75 & 30.93 \\
\hline $\mathrm{CV}(2) \%$ & 25.64 & 30.35 & - & - & 26.55 & 30.18 & 26.50 & 30.25 \\
\hline
\end{tabular}

${ }^{(1)}$ Means followed by equal letters do not differ by Tukey's test, at $5 \%$ probability. $*$ and $* *$ Significant at 5 and $1 \%$ probability, respectively. ${ }^{\mathrm{n}}$ Nonsignificant.

Pesq. agropec. bras., Brasília, v.54, e00039, 2019

DOI: 10.1590/S1678-3921.pab2019.v54.00039 

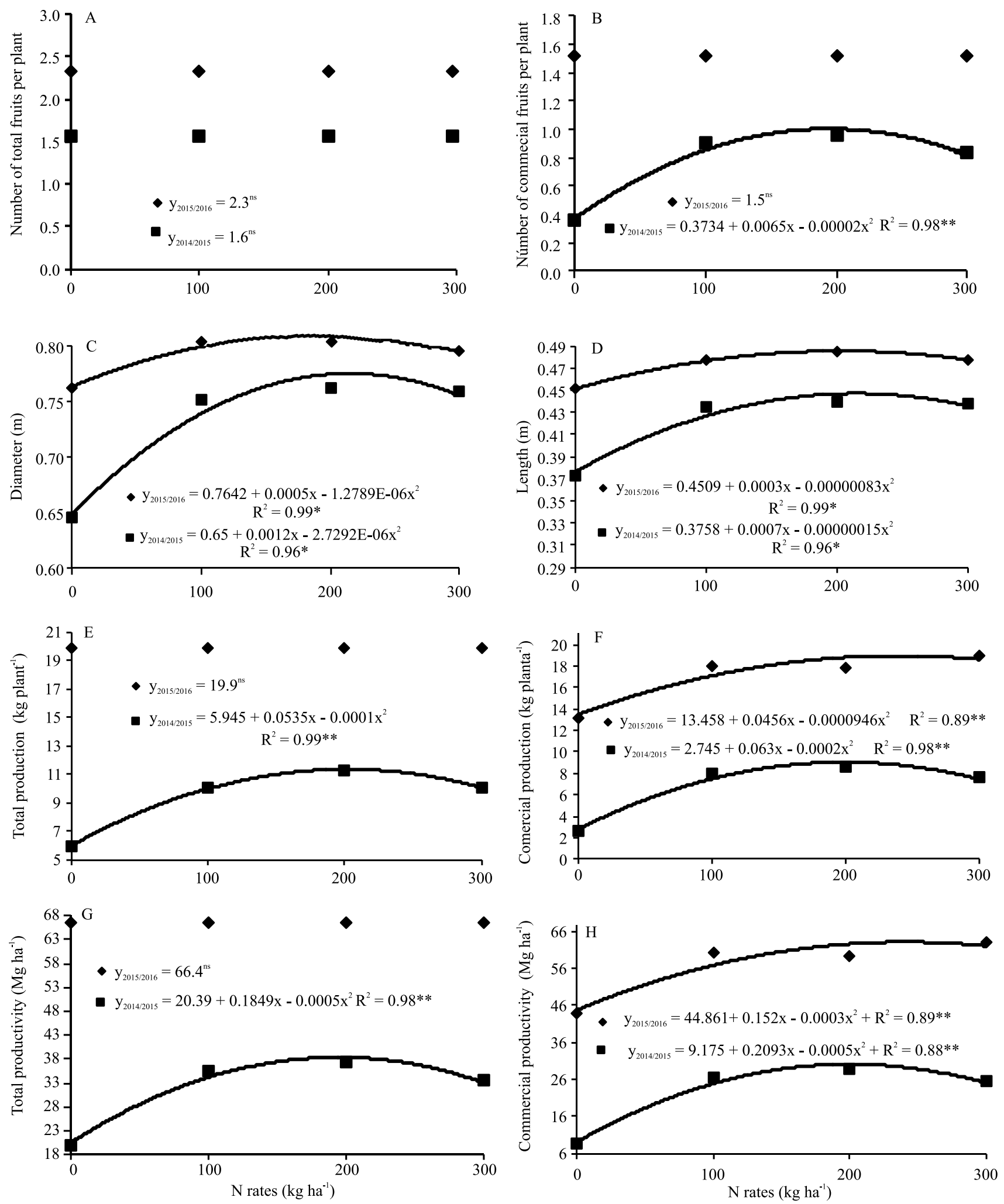

Figure 3. Effect of $\mathrm{N}$ concentrations in the soil cover on the total and commercial number of fruit $(\mathrm{A}, \mathrm{B})$, fruit length $(\mathrm{C})$, fruit diameter (D), total and commercial production (E, F), and total and commercial yield (G, H) of watermelon 'Olímpia' (Citrullus lanatus), in the 2014/2015 and 2015/2016 harvest seasons (equations 1 and 2, respectively) in the municipality of Andradina, in the São Paulo state, Brazil. 


\section{Conclusions}

1. Watermelon (Citrullus lanatus) may be cultivated in regeneration areas of sugarcane field.

2. Watermelon yield in the no-tillage system is similar to that of conventional tillage in the two evaluated harvest seasons.

3. In the 2014/2015 harvest, minimum tillage presented higher commercial yield than other tillage systems.

4. Watermelon yield varied with the increase in $\mathrm{N}$ concentration but was similar between the soil tillage systems evaluated.

\section{References}

ACOMPANHAMENTO DA SAFRA BRASILEIRA [DE] CANA-DE-AÇÚCAR: safra 2016/17: segundo levantamento, v.3, n.2, ago. 2016. Available at: <http://www.conab.gov.br $>$. Accessed on: Nov. 182016.

AMBROSANO, E.J.; CANTARELLA, H.; AMBROSANO, G.M.B.; SCHAMMAS, E.A.; DIAS, F.L.F.; ROSSI, F.; TRIVELIN, P.C.O.; MURAOKA, T.; SACHS, R.C.C.; AZCÓN, R. Produtividade da cana-de-açúcar após o cultivo de leguminosas. Bragantia, v.70, p.810-818, 2011. DOI: https://doi.org/10.1590/S0006-87052011000400012.

BANZATTO, D.A.; KRONKA, S. do N. Experimentação agrícola. 4.ed. Jaboticabal: Funep, 2006. 237p.

BARBOSA, R.M.; HOMEM, B.F.M.; TARSITANO, M.A.A. Custo de produção e lucratividade da cultura do amendoim no município de Jaboticabal, São Paulo. Revista Ceres, v.61, p.475481, 2014. DOI: http://doi.org/10.1590/0034-737X201461040005.

BARROS, M.M.; ARAÚJO, W.F.; NEVES, L.T.B.C.; CAMPOS, A.J. de; TOSIN, J.M. Produção e qualidade da melancia submetida a adubação nitrogenada. Revista Brasileira de Engenharia Agrícola e Ambiental, v.16, p.1078-1084, 2012. DOI: https://doi.org/10.1590/S1415-43662012001000007.

BERNOUX, M.; CERRI, C.C.; CERRI, C.E.P.; SIQUEIRA NETO, M.; METAY, A.; PERRIN, A.-S.; SCOPEL, E.; RAZAFIMBELO, T.; BLAVET, D.; PICCOLO, M. de C.; PAVEI, M.; MILNE, E. Cropping systems, carbon sequestration and erosion in Brazil, a review. Agronomy for Sustainable Development, v.26, p.1-8, 2006. DOI: https://doi.org/10.1051/agro:2005055.

BOLONHEZI, D.; MUTTON, M.Â.; MARTINS, A.L.M. Sistemas conservacionistas de manejo do solo para amendoim cultivado em sucessão a cana crua. Pesquisa Agropecuária Brasileira, v.42, p.939-947, 2007. DOI: https://doi.org/10.1590/S0100-204X2007000700005.

BRANCO, R.B.F.; NOWAKI, R.H.D.; SALLES, F.A.; BOLONHEZI, D.; GUALBERTO, R. Soil properties and agronomic performance of watermelon grown in different tillage and cover crops in the South Eastern of Brazil.
Experimental Agriculture, v.51, p. 299-312, 2014. DOI: https://doi.org/10.1017/S0014479714000313.

CIIAGRO. Centro Integrado de Informações Agrometeorológias. Chuva mensal por local. Available at: $<$ http://www.ciiagro. sp.gov.br/ciiagroonline/Quadros/QChuvaLocal.asp>. Accessed on: Dec. 152016.

FAO. Food and Agriculture Organization of the United Nations. Faostat: Food and Agriculture Organization Statistic. 2014. Available at: <http://www.fao.org/faostat/en/\#data/QC $>$. Accessed on: Oct. 22017.

FARINELLI, R.; LEMOS, L.B. Nitrogênio em cobertura na cultura do milho em preparo convencional e plantio direto consolidados. Pesquisa Agropecuária Tropical, v.42, p.63-70, 2012. DOI: https://doi.org/10.1590/S1983-40632012000100009.

FARINELLI, R.; LEMOS, L.B.; PENARIOL, F.G.; EGÉA, M.M.; GASPAROTO, M.G. Adubação nitrogenada de cobertura no feijoeiro, em plantio direto e convencional. Pesquisa Agropecuária Brasileira, v.41, p.307-312, 2006. DOI: https://doi.org/10.1590/S0100-204X2006000200016.

FERREIRA, D.F. Sisvar: a computer statistical analysis system. Ciência e Agrotecnologia, v.35, p.1039-1042, 2011. DOI: $10.1590 /$ S1413-70542011000600001.

FINOTO, E.L.; MIGUEL, L.Z.M.; CORDEIRO JUNIOR, P.S.; PAULA, L. de; SOARES, M.B.B.; BOLONHEZI, D. Avaliação de genótipos de soja RR e Intacta RR2 Pro ${ }^{\circledR}$ em semeadura direta na reforma de cana crua. Ciência \& Tecnologia: Fatec-JB, v.7, p.1-5, 2015. Número especial.

FORTES, C.; TRIVELIN, P.C.O; VITTI, A.C. Long-term decomposition of sugarcane harvest residues in Sao Paulo state, Brazil. Biomass \& Bioenergy, v.42, p.189-198, 2012. DOI: https://doi.org/10.1016/j.biombioe.2012.03.011.

FORTES, C.; VITTI, A.C.; OTTO, R.; FERREIRA, D.A.; FRANCO, H.C.J.; TRIVELIN, P.C.O. Contribution of nitrogen from sugarcane harvest residues and urea for crop nutrition. Scientia Agricola, v.70, p.313-320, 2013. DOI: https://doi.org/10.1590/S0103-90162013000500005.

GRANGEIRO, L.C.; CECÍllO FILHO, A.B. Acúmulo e exportação de macronutrientes pelo híbrido de melancia Tide. Horticultura Brasileira, v.22, p.93-97, 2004. DOI: https://doi.org/10.1590/S0102-05362004000100019.

JINGGUO, W.; BAKKEN, L.R. Competition for nitrogen during mineralization of plant residues in soil: Microbial response to $\mathrm{C}$ and N availability. Soil Biology and Biochemistry, v.29, p.163-170, 1997. DOI: https://doi.org/10.1016/S0038-0717(96)00292-1.

LEÃO, D.S.S.; PEIXOTO, J.R.; VIEIRA, J.V.; CECÍLIO FILHO, A.B. Produtividade de melancia em diferentes níveis de adubação química e orgânica. Bioscience Journal, v.24, p.32-41, 2008.

NIELSEN, D.R.; BIGGAR, J.W.; WIERENGA, P.J. Nitrogen transport processes in soil. In: STEVENSON, F.J. (Ed.). Nitrogen in agriculture soils. Madison: American Society of Agronomy, 1982. p.423-448.

ROCHA, M.R. da; ELTZ, F.L.F.; SANTOS, M.S. dos; ROCHA, P.V. da; GOULART, R.Z. Produtividade, qualidade dos frutos e distribuição do sistema radicular da melancia em diferentes 
sistemas de cultivo. Revista Brasileira de Ciência do Solo, v.35, p.1377-1386, 2011. DOI: https://doi.org/10.1590/S010006832011000400032 .

SANTIAGO, A.A.; ROSETTO, R. Produção: manejo: rotação e reforma. In: MARIN, F.R. (Ed.). Árvore do conhecimento: cana-de-açúcar. Brasília: Embrapa, 2008. Available at: <http:// www.agencia.cnptia.embrapa.br/gestor/cana-de-acucar/arvore/ CONTAG01_84_22122006154841.html>. Accessed on: Fev. 242014.

SANTOS, H.G. dos; JACOMINE, P.K.T.; ANJOS, L.H.C. dos; OLIVEIRA, V.A. de; OLIVEIRA, J.B. de; COELHO, M.R.; LUMBRERAS, J.F.; CUNHA, T.J.F. (Ed.). Sistema brasileiro de classificação de solos. 2.ed. Brasília: Embrapa, 2006. 306p.

SILVA, M.G.O. da; FREITAS, F.C.L. de; NEGREIROS, M.Z. de; MESQUITA, H.C. de; SANTANA, F.A.O. de; LIMA, M.F.P. de. Manejo de plantas daninhas na cultura da melancia nos sistemas de plantio direto e convencional. Horticultura Brasileira, v.31, p.494-499, 2013. DOI: https://doi.org/10.1590/S010205362013000300025.

SIMPÓSIO SOBRE NITROGÊNIO E ENXOFRE NA AGRICULTURA BRASILEIRA, 2006, Piracicaba. Nitrogênio e enxofre na agricultura brasileira: anais. Piracicaba: IPNI, 2007. 722p. Editores: Tsuioshi Yamada, Silvia Regina Stipp e Abdalla, Godofredo Cesar Vitti.

SOARES, J.I.; COSTA, R.N.T.; SILVA, L.A.C. da; GONDIM, R.S. Função de resposta da melancia aos níveis de água e adubação nitrogenada, no Vale do Curu, CE. Revista Brasileira de Engenharia Agrícola e Ambiental, v.6, p.219-224, 2002. DOI: https://doi.org/10.1590/S1415-43662002000200006.

TIVELLI, S.W.; PURQUERIO, L.F.V.; KANO, C. Adubação verde e plantio direto em hortaliças. Pesquisa e Tecnologia, v.7, p.1-8, 2010. Available at: <http://www.aptaregional.sp.gov.br/acesseos-artigos-pesquisa-e-tecnologia/edicao-2010/2010-janeiro- junho/714-adubacao-verde-e-plantio-direto-em-hortalicas/file. html>. Accessed on: Nov. 182016.

TRANI, P.E.; PASSOS, F.A.; NAGAI, H.; MELO, A.M.T. Melão e melancia. In: RAIJ, B. van; CANTARELLA, H.; QUAGGIO, J.A.; FURLANI, A.M.C. Recomendações de adubação e calagem para o Estado de São Paulo. 2.ed. rev. e ampl. Campinas: IAC, 1997. p.181 (IAC. Boletim técnico, 100).

TRIVELLIN, P.C.O.; FRANCO, H.C.J.; OTTO, R.; FERREIRA, D.A.; VITTI, A.C.; FORTES, C.; FARONI, C.E.; OLIVEIRA, E.C.A.; CANTARELLA, H. Impact of sugarcane trash on fertilizer requirements for São Paulo, Brazil. Scientia Agricola, v.70, p.345-352, 2013. DOI: https://doi.org/10.1590/S010390162013000500009.

VITTI, A.C.; FERREIRA, D.A.; FRANCO, H.C.J.; FORTES, C.; OTTO, R.; FARONI, C.E.; TRIVELIN, P.C.O. Utilisation of nitrogen from trash by sugarcane ratoons. International Sugar Journal, v.28, p.249-253, 2010.

VITTI, A.C.; FRANCO, H.C.J.; TRIVELLIN, P.C.O.; FERREIRA, D.A.; OTTO, R.; FORTES, C.; FARONI, C.E. Nitrogênio proveniente da adubação nitrogenada e de resíduos culturais na nutrição da cana-planta. Pesquisa Agropecuária Brasileira, v.46, p.287-293, 2011. http://doi.org/10.1590/S0100204X2011000300009.

VITTI, A.C.; TRIVELIN, P.C.O.; CANTARELLA, H.; FRANCO, H.C.J.; FARONI, C.E.; OTTO, R.; TRIVELIN, M.O.; TOVAJAR, J.G. Mineralização da palhada e crescimento de raízes de cana-de-açúcar relacionados com a adubação nitrogenada de plantio. Revista Brasileira de Ciência do Solo, v.32, p.2757-2762, 2008. Número especial. DOI: https://doi.org/10.1590/S0100-06832008000700020. 